Research Article

\title{
Linkage and mapping of quantitative trait loci associated with angular leaf spot and powdery mildew resistance in common beans
}

Denis Bassi ${ }^{1}$, Boris Briñez ${ }^{1}$, Juliana Santa Rosa ${ }^{1}$, Paula Rodrigues Oblessuc ${ }^{1}$, Caléo Panhoca de Almeida ${ }^{1}$, Stella Maris Nucci $^{1}$, Larissa Chariel Domingos da Silva ${ }^{1}$, Alisson Fernando Chiorato ${ }^{2}$, Rosana Pereira Vianello ${ }^{3}$, Luis Eduardo Aranha Camargo ${ }^{4}$, Matthew Wohlgemuth Blair ${ }^{5}$ and Luciana Lasry Benchimol-Reis ${ }^{1}$

${ }^{1}$ Centro de Recursos Genéticos Vegetais, Instituto Agronômico de Campinas (IAC), Campinas, SP, Brazil

${ }^{2}$ Centro de Grãos e Fibras, Instituto Agronômico de Campinas (IAC), Campinas, SP, Brazil.

${ }^{3}$ Centro Nacional de Pesquisa de Arroz e Feijão, EMBRAPA, Santo Antônio de Goiás, GO, Brazil.

${ }^{4}$ Departamento de Fitopatologia, Escola Superior de Agricultura Luiz de Queiroz (ESALQ), Universidade de São Paulo (USP), Piracicaba, SP, Brazil.

${ }^{5}$ Department of Agriculture and Environmental Sciences, Tennessee State University, Nashville, TN, USA.

\begin{abstract}
Angular leaf spot (ALS) and powdery mildew (PWM) are two important fungi diseases causing significant yield losses in common beans. In this study, a new genetic linkage map was constructed using single sequence repeats (SSRs) and single nucleotide polymorphisms (SNPs), in a segregating population derived from the AND 277 x SEA 5 cross, with 105 recombinant inbred lines. Phenotypic evaluations were performed in the greenhouse to identify quantitative trait loci (QTLs) associated with resistance by means of the composite interval mapping analysis. Four QTLs were identified for ALS resistance. The QTL ALS11 ${ }^{\text {AS }}$, linked on the SNP BAR 5054, mapped on chromosome PV11, showed the greatest effect $\left(R^{2}=26.5 \%\right)$ on ALS phenotypic variance. For PWM resistance, two QTLs were detected, $\mathrm{PWM}_{2}^{\mathrm{AS}}$ and PWM11 $1^{\mathrm{AS}}$, on Pv2 and Pv11, explaining $7 \%$ and $66 \%$ of the phenotypic variation, respectively. Both QTLs on Pv11 were mapped on the same genomic region, suggesting that it is a pleiotropic region. The present study resulted in the identification of new markers closely linked to ALS and PWM QTLs, which can be used for marker-assisted selection, fine mapping and positional cloning.
\end{abstract}

Keywords: Pseudocercospora griseola; Erysiphe polygoni; quantitative inheritance; SSRs; SNPs.

Received: December 08, 2015; Accepted: June 20, 2016.

\section{Introduction}

Common bean (Phaseolus vulgaris L.) represents an important source of protein in the human diet, especially in developing countries (Gepts et al., 2008). The species is cultivated in several countries around the world, and Brazil is the second leading producer and the largest consumer (FAOStat, 2014). Angular leaf spot (ALS) caused by Pseudocercospora griseola (Sacc.) Crous \& Braun (sin. Phaeoisariopsis griseola (Sacc.) Ferraris) (Crous et al., 2006) severely reduces common bean yield in tropical and subtropical regions. This disease occurs in more than 60 countries including Brazil, and depending on the environmental and management conditions the losses can reach up to $80 \%$ (Schwartz et al., 1982; Jesus Júnior et al., 2001).

Send correspondence to Luciana Lasry Benchimol-Reis. Instituto Agronômico (IAC) - Centro de Recursos Genéticos Vegetais, Av. Barão de Itapura, no 1481, Botafogo, 13020-432, Campinas, SP, Brazil. E-mail: llasry@iac.sp.gov.br
This disease causes necrotic lesions in the leaves, pods, and stems. Lesions may also appear on the seeds, resulting in losses in grain productivity and quality.

Powdery mildew (PWM), caused by Erysiphe polygoni DC (Ferreira et al., 1999) is another disease that causes serious damage to bean crops. Although it has a worldwide distribution, it is considered a secondary disease (Sartorato et al., 1996). However, the incidence of this disease has increased in recent years, mainly due to increased planting of winter crops, where environmental conditions are favorable to the development of pathogens (Rezende $e t$ al., 1999). Losses can reach $69 \%$, mainly when the infection occurs before the anthesis (Hall, 1991). Initial symptoms are characterized by small round spots on the leaves or stems, which grow and form a whitish mycelial mass at later stages of infection, covering the entire plant (Schwartz et al., 2005).

Among the various strategies of management, the most efficient and economical one has been the use of resis- 
tant cultivars. However, the high genetic variability observed in these pathogens has facilitated the development of different physiological races (Schwartz, 1994; PastorCorrales and Jará, 1995; Silva et al., 2008), and consequently, it is difficult to obtain varieties with large degree of resistance. Resistant sources to angular leaf spot have been identified (Pastor-Corrales et al., 1998; Mahuku et al.. 2003; Sartorato, 2006), of which the majority were described with monogenic dominant or recessive inheritance pattern (Carvalho et al., 1998; Gonçalves-Vidigal et al., 2011; Mahuku et al., 2011). Cultivar AND 277 is distinguished by possessing Phg-1, Phg- $2^{2}, P h g 3^{2}$ and $P h g-4^{2}$ alleles that confer resistance to nine races of angular leaf spot, which include the races 63.23 and 63.19 , frequently found in Brazilian planting areas (Alzate-Marin et al., 2003; Caixeta et al., 2005; Reis-Prado, 2006).

Sources of resistance to PWM have also been described (Schwartz et al., 1981), including 'Cornel 49242', 'Porrillo Sintético', 'Negro San Luis' and 'ESAL 686' cultivars (Rezende et al., 1999; Trabanco et al., 2012; Pérez-Vega et al., 2013). Much of these sources are characterized by possessing a few genes involved in the trait with different patterns of action.

In addition to the studies that observed qualitative genetic inheritance, there is also evidence of quantitative trait loci (QTLs) controlling ALS resistance (López et al., 2003; Mahuku et al., 2009, 2011; Oblessuc et al., 2012, 2013, 2015; Keller et al., 2015). Five QTLs were mapped on linkage group Pv04, one on Pv08, another on Pv09 and three on Pv10 (López et al., 2003; Mahuku et al., 2009, 2011). Mahuku et al. (2011) identified two resistance genes on the G10909 cultivar. In addition, Caixeta et al. (2005) observed by alelism tests three genes (Phg-3, Phg-4 and Phg-5) with two alleles each, controlling the resistance in four cultivars ('AND 277', 'Mexico 54', 'MAR 2'and 'Cornell 49-242') that were previously characterized as having only one resistance gene QTL associated to PWM resistance (Melo et al., 2002; Hanai et al., 2010). These results strengthen the evidence that the type of genetic inheritance involved in the resistance to ALS and PWM is more complex than that described by several authors, and additional studies need to be conducted to better understand these host-pathogen relationships.

Molecular-genetic maps and QTL mapping are tools that allow the localization of some genomic regions that control both single and complex inheritance, making possible the study of the genetic architecture of the traits of interest (Lynch and Walsh, 1998), such as resistance to diseases. From a breeding perspective, it is interesting to have maps fully saturated with markers, indicating genes and/or QTLs locations (Hanai et al., 2010). This information could be used in breeding programs for producing new cultivars by marker-assisted selection and for helping breeders understand the effects and mode of action of loci that control the traits of interest.
Several linkage maps have been constructed for $P$. vulgaris (Blair et al., 2007; Grisi et al., 2007; Campos et al., 2011; Oblessuc et al., 2014). The construction of new maps using populations that have not been previously mapped is interesting for integrating mapping studies, synteny analysis, and discovering and validating new QTLs.

In this study, we aimed to (1) validate effective ALS and PWM resistance loci in common beans and (2) develop closely linked markers for breeding applications.

\section{Materials and Methods}

\section{Plant material}

The mapping population was composed of 105 recombinant inbred lines (RILs) in the $\mathrm{F}_{8}$ generation. This population was obtained by the crossing between AND 277 and SEA 5 cultivars at the International Center for Tropical Agriculture (CIAT, Cali, Colombia). SEA 5 belongs to the Mesoamerican gene pool and it is susceptible to angular leaf spot. Singh et al. (2001) registered the line SEA 5 as a drought tolerant cultivar, derived from interracial crosses between the races Mesoamerican and Durango, and one of the parents originating the line was the cultivar BAT 477, also described by the authors as drought tolerant. Later, Terán and Singh (2002) also observed productive superiority of the genotype SEA 5 in both water deficit and under irrigated condition, using BAT 477 and San Cristobal 83 as tolerant controls. Studying the root system by means of a screening using soil tube system to evaluate the impact of drought on different genotypes of beans, Rao et al. (2006) found that SEA 5 and BAT 477 remained among the genotypes with deeper roots. SEA 5 was also used in studies for drought tolerance and other traits of agronomic interest (Blair et al., 2006).

AND277 from the Nueva Granada race belongs to the Andean gene pool (Blair et al., 2009) and it was also developed at CIAT (Cali, Colombia). Cultivar AND 277 [Cargabello x (Pompadour ChecaxLínea 17) x (Línea 17 x Red Kloud)] is an important resistance source used in breeding programs in Brazil and Southern Africa (Carvalho et al., 1998, Gonçalves-Vidigal et al., 2011). AND 277 has the Co- $1^{4}$ allele that confers resistance to C. lindemuthianum (Arruda et al., 2008) and the Phg-1 ALS-resistance gene that confers resistance to some Brazilian P. griseola races (Caixeta et al., 2005). In greenhouse evaluations, AND 277 showed resistance to races 63.23 e 63.19 known as severe and highly frequent in Brazilian bean field. (Reis-Prado, 2006). SEA 5 x AND 277 population also detains contrast in relation to drought tolerance and was used in mapping studies in common bean (Briñez Rodriguez, 2013). This same breeding population was used in evaluating drought tolerance in greenhouse conditions (data not shown). 


\section{Characterization and genotyping of the AS} population with SSRs

Genomic DNA was isolated from the RIL and parental leaves, following the protocol described by CIMMYT (2005). A total of 328 SSRs (Hanai et al., 2007; Campos et al., 2011) were characterized and the ones that were polymorphic in the parents were selected to construct the molecular-genetic map. PCR products were separated in polyacrylamide gel electrophoresis (PAGE) (6\%) and revealed by silver staining.

\section{SNP genotyping}

A total of 384 SNPs, previously identified for $P$. vulgaris (Müller et al., 2015) polymorphic between BAT 93 (Mesoamerican) and JALO EEP558 (Andean) lines, was genotyped by Vera Code ${ }^{\circledR}$ technology with Bead X press platform (Illumina) and selected to compose the oligopool assay (OPA).

Three oligonucleotides were used for each of the variations of the same SNP and the third specific-locus binding to the 3' region of the DNA fragment containing the target SNP, generating a unique allele-specific fragment. Subsequently, this fragment was amplified using Taq DNA polymerase enzyme Titanium (Clontech $\left.{ }^{\circledR}\right)$ and complementary primers labeled with $C y 3$ and $C y 5$ fluorophores.

Genotyping was realized by Genome Studio software version 1.8.4 (Illumina, EUA) using Call Rate values ranging from 0.80 to 0.90 and GenTrain $\geq 0.26$ for SNP grouping. Automated analyses were performed to cluster the SNP alleles of each line, based on the signal intensity for $C y 3$ and $C y 5$ fluorophores, resulting in three genotype classes, $\mathrm{AA}, \mathrm{BB}$, and AB. Groups were adjusted individually and manually by determining the best clusters based on the parental profile.

\section{Linkage map construction}

Segregation analysis for 105 RILs and parents was done by Chi-Square test and $p$-values associated with the test were calculated using $\mathrm{R}$ statistical software (version 2.12.2, R Development Core Team, 2011). The genetic map was constructed by OneMap software, version 2.0-1 (Margarido et al., 2007), using multipoint approaches and Markov models, adopting a likelihood of odds (LODscore) limited ratio of 3.0 and maximum genetic distance of $37.5 \mathrm{cM}$ as thresholds by using the Kosambi mapping function (Kosambi, 1944).

The molecular markers' probable physical location in the chromosomes was verified by BLASTN analysis (Altschul et al., 1997) using the P. vulgaris genome (https://phytozome.jgi.doe.gov/pz/portal.html; Schmutz et al., 2014) and by comparisons with integrated genetic maps for the common bean, based on SSRs mapping (Blair et al., 2011; Campos et al., 2011). The nomenclature described by Pedrosa-Harand et al. (2008) was used. The design of each linkage group with markers in their respective positions and distances was done with MapChart 2.2 program (Voorrips, 2002).

\section{Angular leaf spot and powdery mildew evaluations}

The $P$. griseola isolates were obtained from naturally ALS-infected bean leaves collected from the Agronomic Institute (IAC, Campinas, SP. Brazil) fields, in different bean growing areas, and characterized into races based on their reactions in the twelve internationally differential bean cultivars (Pastor-Corrales and Jara, 1995).

Inoculation $\left(2 \times 10^{4}\right.$ spores $\left.\mathrm{mL}^{-1}\right)$ was conducted during the period in which plants reached the $\mathrm{V} 3$ phenological stage, in an acclimatized room. Plants were kept at a relative humidity (RH) $>95 \%$ and temperature of $22{ }^{\circ} \mathrm{C}$ for 48 $\mathrm{h}$ and then transferred to the greenhouse. Symptoms were evaluated 15 days after inoculation. Plants were scored for disease severity using a 1-9 scoring scale (Van-Schoonhoven and Pastor-Corrales, 1991). Parental evaluation was performed in the same experiment as checks. Digital analysis using Image $J^{\circledR}$ software (Rasband, 2014) was also processed, considering the number of lesions, lesion area $\left(\mathrm{cm}^{2}\right)$, and percentage affected.

A completely randomized greenhouse block design was used, with four replications and plots consisting of boxes of $29.5 \mathrm{~cm} \times 46.5 \mathrm{~cm} \times 12.5 \mathrm{~cm}$, filled with commercial substrate $\left(\right.$ Plantmax $\left.^{\circledR}\right)$ prepared with pine bark. Seeds from three different RILs were planted in three rows in each box, with each one corresponding to a recombinant inbred line. Rows consisted of four plants, spaced approximately 4 $\mathrm{cm}$ from each other, resulting in 12 plants per box. NPK 04-14-08 fertilization was performed at a dose of $400 \mathrm{~L}$ $\mathrm{ha}^{-1}$. Carioca cultivar was also used as checks. Infection caused by E. polygoni occurred naturally. Disease severity evaluations occurred thirty days after planting and performed with the aid of diagrammatic notes developed by Blum et al. (2003), based on infection percentage (Table $\mathrm{S} 1)$.

\section{Statistical analysis}

The average of notes generated from four plants per RIL per block corresponded to the final disease score of each line. These values were used for analysis of variance and $\mathrm{F}$ tests using the general linear models (GLM) procedure, using SAS software v.8.2 (SAS Institute, Cary, NC, USA). Broad sense heritability $\left(\mathrm{h}^{2}\right)$ was estimated according to Falconer and Mackay (1996). In order to confirm the contrasting resistance profile among genotypes, separate analyses were performed for the parents and recombinant inbred lines. Effects of different sources of variation were considered significant by $\mathrm{F}$ test when $\mathrm{P} \leq 0.05$. Skewness, kurtosis (Mardia, 1970) and Shapiro and Wilk (1965) normality tests were applied to verify normal distribution of variance analysis residuals. 


\section{Mapping resistance loci associated to angular leaf} spot and powdery mildew

QTL Cartographer software v1.17 (Basten et al., 2005) was used, applying composite interval mapping with model selection based on Bayesian Information Criterion for choosing the best model, including or excluding the main effects of QTLs (Zeng et al., 1999).

Likelihood ratio tests (LRT) were used to verify the presence and effect of identified QTLs. LOD values were calculated using the formula LOD $=0.2172 \times$ LRT. Multiple linear regression for each linkage group position was applied considering the level of significance equal to $\alpha=$ 0.05 .

The significance value for detection of QTLs was determined by performing tests with 1000 permutations (Churchill and Doerge, 1994). R2 values and additive effects of each QTL were identified. Positive effect values are related alleles that increase the susceptibility, while negative effects are related to the action of resistance alleles.

\section{Location and functional analyses of markers linked to QTLs}

The genome location of all markers present in the interval of QTLs was verified by the alignment to the bean genome available on Phytozome v10.3 database (https://phytozome.jgi.doe.gov/pz/portal.html). The criteria used to assign putative regions to the markers included E-values $\leq 1 \times 10^{-10}$ and minimum identity of $50 \%$ between query and database sequences. The closest transcripts to each marker were annotated for their putative function, with the goal of analyzing the genomic context of the QTLs mapped.

\section{Results and Discussion}

\section{AS population genotyping}

A total of 150 (46\%) SSRs were polymorphic between the AS parents. A similar polymorphism ratio was observed in other studies (Yu et al., 2000; Grisi et al., 2007). Among the polymorphic SSRs markers, $24 \%$ were of composite-type, $20 \%$ dinucleotides, $24 \%$ trinucleotides, and $13 \%$ tetranucleotides. It is important to consider the nature of the SSR motives, such as length and number of repeat units to select the best markers suited for genotyping (Garcia et al., 2011).

For SNPs, 288 (75\%) were polymorphic between the AS parents. Among them, $9 \%$ were heterozygous, and were thus not included in the mapping analysis. According to the literature, there is a broad distribution of SNPs throughout the bean genome (Gaitán-Solís et al., 2008; Souza et al., 2012).

\section{Construction of the AS map}

All the SSRs and SNPs showed the expected Mendelian segregation ratio of 1:1. Among the 150 polymorphic SSR markers, 80 (53\% of total) were used in the mapping analysis. A total of 251 SNP markers were used in the analysis due to the exclusion of those with heterozygous profiles. In total, 331 markers were linked to the 11 chromosomes (Figure 1) of common beans, resulting in a map length of 1,515.2 $\mathrm{cM}$ and an average distance between markers of $4.5 \mathrm{cM}$.

The SNPs and SSRs were distributed in all linkage group chromosomes (Table 1), ranging from 17 (Pv09) to 31 SNPs (Pv11), and 4 (Pv11) to 11 SSRs (Pv02). The size of the bean chromosomes ranged from $63.1 \mathrm{cM}$ (Pv10) to $221.2 \mathrm{cM}$ (Pv01). Pv04 and Pv09 presented the lowest number of linked loci, while Pv03 and Pv01 showed the highest number of linked markers. The order of the markers on $\mathrm{Pv} 03$ was maintained when compared with previous studies (Cordoba et al., 2010; Campos et al., 2011; Garcia et al., 2011). In addition, BLASTN analysis confirmed the correct association of markers on common bean chromosomes using the Phytozome database.

In the AS map, it was possible to associate 276 new loci, with no gaps between them, providing a new tool for synteny studies, map integration, and mapping of agronomically important traits.

\section{Identification of physiological races of $P$. griseola and parental characterization}

Each isolate collected in the Agronomic Institute fields corresponded to a different race of Mesoamerican origin (isolate IAC-1, race 1.21; isolate IAC-2: race 1.5; isolate IAC-3: race 0.22 ). These different races in the collecting area may be due to the high genetic variability observed within the species (Sartorato, 2002; Mahuku et al., 2003).

All races caused symptoms in the susceptible SEA 5 parent. However, race 1.21, (isolate IAC-1) caused the most severe symptoms and therewith, it was chosen to be used in the disease response evaluations of the whole mapping population. The average severity score measured among the four AND 277 parental plants was 1, characterizing it as highly resistant. The average severity score of SEA 5 was 6.2 , characterizing it as susceptible.

The parameters [number of lesions, lesion area $\left(\mathrm{cm}^{2}\right)$, and leaf affected percentage (\%)] evaluated with Image ${ }^{\circledR}$ for the AND 277 parent were all 0, showing high resistance; unlike the SEA 5 parent, where the number of lesions (27), lesion area $\left(19.35 \mathrm{~cm}^{2}\right)$, and leaf affected percentage $(52.48 \%)$, revealed susceptibility to angular leaf spot. Therewith, processing and analyzing of digital images (Figure S1) confirmed the resistance and susceptibility profiles of AND 277 and SEA5, respectively.

These results were consistent with the levels of resistance reported in other studies for AND 277 (Aggarwal et al., 2004; Reis-Prado, 2006; Gonçalves-Vidigal et al., 

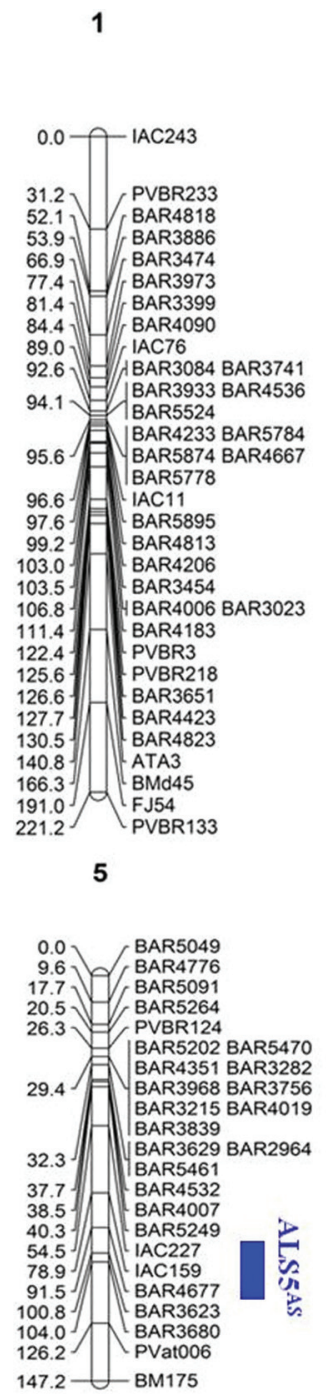

9

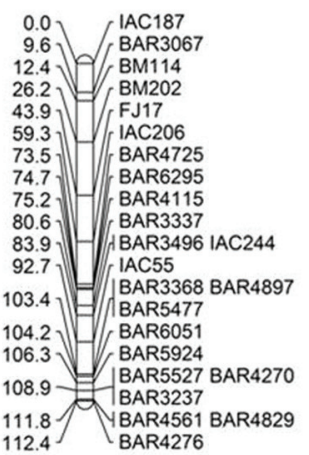

$\left.\begin{array}{r}0.0 \\ 34.6 \\ 43.3 \\ 50.7 \\ 59.1 \\ 66.7 \\ 72.9 \\ 75.4 \\ 77.2 \\ 78.9 \\ 81.1 \\ 81.6 \\ 83.7 \\ 84.0 \\ 84.2 \\ 95.4 \\ 96.0 \\ 100.0 \\ 101.3 \\ 109.0 \\ 117.5 \\ 123.7 \\ 129.7 \\ 132.4 \\ 134.0 \\ 141.2 \\ 143.0 \\ 149.5 \\ 151.2 \\ 161.4\end{array}\right]$ [-

$\left.\begin{array}{l}151.2 \\ 161.4\end{array}\right]$ BAR3812

$\left.\begin{array}{r}0.0 \\ 5.4 \\ 16.5 \\ 21.2 \\ 25.0 \\ 34.7 \\ 49.9 \\ 71.5 \\ 82.7 \\ 83.8 \\ 88.5 \\ 92.2 \\ 99.2 \\ 108.6 \\ 116.1 \\ 119.2 \\ 120.4 \\ 120.9 \\ 123.0 \\ 126.2 \\ 129.2 \\ 129.9 \\ 130.7 \\ 131.4\end{array}\right]=\left[\begin{array}{l}\text { PVM95 } \\ \text { PVBR255 } \\ \text { BM189 } \\ 134.1 \\ 135.5 \\ 137.0 \\ \text { BAR3262 } \\ 137.7 \\ \text { BAR5304 } \\ 139.1 \\ 142.0 \\ 159.4\end{array}\right]$ BMd36

6

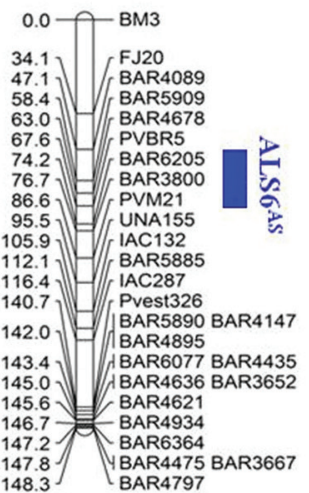

7

$\left.\begin{array}{l}0.0 \\ 15.9 \\ 24.0 \\ 48.3 \\ 43.3 \\ 44.3 \\ 45.4 \\ 46.4 \\ 48.4 \\ 49.0 \\ 51.2 \\ 54.4 \\ 56.6 \\ 63.1 \\ 85.9 \\ 87.0 \\ 90.9 \\ 92.7 \\ 110.4 \\ 137.7 \\ 140.7 \\ 152.8 \\ 179.6\end{array}\right]$ BMC229

4

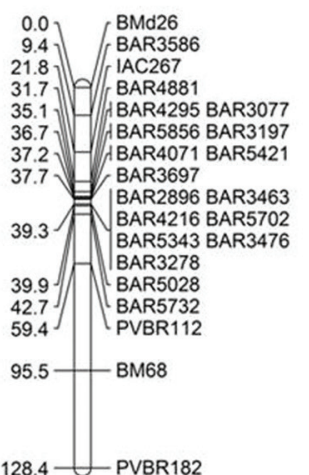

$28.4-$ PVBR182

(2) 
Table 1 - Distribution of SSRs and SNPs, number of loci, linkage group length and average distance between markers in the genetic map developed from the AND277xSEA5(AS) population using OneMap ${ }^{\circledR}$ software.

\begin{tabular}{lccccc}
\hline $\begin{array}{l}\text { Linkage } \\
\text { group }\end{array}$ & SSR & SNP & $\mathrm{N}^{\text {o }}$ of loci & $\begin{array}{c}\text { Length } \\
\text { (bp) }\end{array}$ & $\begin{array}{c}\text { Average distance } \\
\text { between loci }(\mathrm{cM})\end{array}$ \\
\hline Pv01 & 10 & 26 & 36 & 221.2 & 6.1 \\
Pv02 & 11 & 21 & 32 & 161.4 & 5.0 \\
Pv03 & 10 & 30 & 40 & 159.4 & 3.9 \\
Pv04 & 5 & 18 & 23 & 128.4 & 5.5 \\
Pv05 & 5 & 22 & 27 & 147.2 & 5.4 \\
Pv06 & 8 & 19 & 27 & 148.2 & 5.4 \\
Pv07 & 8 & 22 & 30 & 179.6 & 5.9 \\
Pv08 & 7 & 22 & 29 & 86.7 & 2.9 \\
Pv09 & 7 & 17 & 24 & 112.4 & 4.6 \\
Pv10 & 5 & 23 & 28 & 63.1 & 2.2 \\
Pv11 & 4 & 31 & 35 & 107.5 & 3.0 \\
Total & 80 & 251 & 331 & 1515.2 & 4.5 \\
\hline
\end{tabular}

2011), making it a promising line for common bean breeding programs aiming for ALS resistance.

\section{Disease evaluation of the AS population}

Normality test (skewness, kurtosis, and ShapiroWilk) results were not significant, indicating normal distribution for residuals associated with analysis of phenotypic values of ALS and PWM symptoms evaluations (Skewness ALS, $\mathrm{P}=0.66$; kurtosis ALS, $\mathrm{P}=0.94$; Shapiro-Wilk ALS, $\mathrm{P}=0.98$; skewness $\mathrm{PWM}, \mathrm{P}=0.16$; kurtosis $\mathrm{PWM}, \mathrm{P}=$ 1.71; Shapiro-Wilk PWM, P = 0.98)

Analysis of variance and F test for severity of ALS and PWM detected significant differences between parents and RILs. The high variability between the lines was confirmed by highly significant values for the $\mathrm{F}$ test (F-value equal to 2.3 and $12.6, \mathrm{P}<0.0001$ to ALS and PWM, respectively), for all genotypes, supporting the hypothesis that the AS population is representative for mapping resistance loci.

The contrasting parental profile in relation to ALS resistance was again evidenced in the assay with the 105 RILs (Table 2). The same profile was found for PWM; however, SEA 5 behaved as moderately resistant and AND 277 as susceptible (Table 2).

Broad sense heritability to ALS resistance was considered moderate to high (Table 2). Similar values were

Table 2 - Estimates of means, standard deviations and broad sense heritabilities for angular leaf spot and powdery mildew resistances.

\begin{tabular}{lcc}
\hline Genotypes & Angular leaf spot & Powdery mildew \\
\hline AND 277 & $1.1 \pm 1.0^{*}$ & $5.6 \pm 0.8^{*}$ \\
SEA 5 & $3.4 \pm 1.0^{*}$ & $3.8 \pm 0.8^{*}$ \\
\hline
\end{tabular}

* Significant differences at 0.05 of probability also estimated in other studies. Oblessuc et al. (2012) estimated a value of 0.69 in greenhouse assays. Miklas et al. (2001) observed a value of 0.65 to white mold resistance. According to Amaro et al. (2007), the values of heritability estimated to ALS resistance are usually high, allowing phenotypic selection for recombination to be performed in the $\mathrm{F}_{2}$ generation.

The estimate of broad sense heritability for PWM was higher than ALS resistance (Table 2). Kasettranan et al. (2010) estimated values of 0.94 in field conditions and 0.92 in greenhouse assays for PWM heritability, using RIL populations. These values suggest that the PWM resistance trait suffers less environmental influence favoring gains with few selection cycles.

Transgressive segregation in resistance and susceptibility to both studied diseases was observed (Figure S2), which provides evidence for the presence of minor genes for the resistance to these diseases in both SEA 5 and AND 277. Oblessuc et al. (2012) also observed transgressive segregation to ALS in greenhouse and field assays. One possible cause for the occurrence of transgressive segregation is the presence of complementary genes with additive effects within the parents (Beebe et al., 2008) that, when combined, result in higher or lower phenotypic expression.

\section{QTLs associated with resistance to ALS and PWM}

Threshold values obtained by permutation analysis revealed six resistance QTLs for both studied diseases (Figures 1 and 2), of which four were associated with ALS and two with PWM, mapped on Pv02, Pv05, P06, Pv10, and Pv11. Three QTLs were mapped in regions covering SNP markers such as the BAR3800 which was the marker closest to the maximum LOD score for the ALS6 ${ }^{\mathrm{AS}}$, mapped between BAR6205 and PVM21 markers, on Pv06. For Pv10, the BAR5771, located between BAR576 and BAR4354 was the marker closest to the maximum LOD score for the QTL ALS10 ${ }^{\text {AS }}$. The BAR5054 marker was also located on the ALS11 ${ }^{\mathrm{AS}}$ and PWM11 ${ }^{\mathrm{AS}}$ QTL peaks, on Pv11, between BAR5764 and BAR5793 markers. Two QTLs were mapped in these regions, covering SSR markers, such as the IAC159, located between IAC227 and BAR4677 markers on Pv05, closest to the maximum LOD score for the $\mathrm{ALS}^{\mathrm{AS}}$, and the PVBR149 located on Pv2, between BAR3703 and BAR3999 markers, closest to the maximum LOD score for the PWM2 ${ }^{\text {AS }}$ (Table 3).

Several resistance QTLs to bean white mold have been identified on Pv2, Pv5, and Pv6 (Kolkman and Kelly, 2003; Ender and Kelly, 2005; Miklas, 2007). Jung (1998) mapped the gene that confers resistance to rust $(P u)$ on Pv5. Corrêa et al. (2001) mapped resistance genes to rust on Pv10. Navarro et al. (2007) identified resistance QTLs associated with bacterial brown spot on Pv6 and Pv11. Campa et al. (2014) identified a complex cluster of bean anthracnose resistance genes at the end of Pv11. Oblessuc et al. (2012) identified a major QTL associated to angular 
Table 3 - QTLs to angular leaf spot and powdery mildew resistance mapped in the AND 277 x SEA5 RIL common bean population using 80 SSRs and 251 SNPs.

\begin{tabular}{|c|c|c|c|c|c|c|c|}
\hline Disease & LG & QTL & Interval (cM) & Marker & LOD & Additive Effect & R2 (\%) \\
\hline ALS & $\mathrm{Pv} 05$ & $\mathrm{ALS}^{\mathrm{AS}}$ & $79.2-104.3$ & IAC159 & 3.26 & 0.38 & 15.3 \\
\hline ALS & Pv06 & ALS6 ${ }^{\text {AS }}$ & $67.6-98.5$ & BAR3800 & 3.86 & -0.36 & 14.4 \\
\hline ALS & Pv10 & $\operatorname{ALS} 10^{\mathrm{AS}}$ & $21-40$ & BAR5771 & 3.87 & -0.35 & 13.7 \\
\hline ALS & Pv11 & $\operatorname{ALS} 11^{\mathrm{AS}}$ & $78.6-107.7$ & BAR5054 & 4.39 & -2.45 & 26.5 \\
\hline PWM & $\mathrm{Pv} 02$ & PWM2 ${ }^{A S}$ & $136-149.5$ & PVBR149 & 3.88 & -0.47 & 7.3 \\
\hline PWM & Pv11 & PWM11 ${ }^{\text {AS }}$ & $79.3-107.7$ & BAR5054 & 29.6 & 1.53 & 66.5 \\
\hline
\end{tabular}

$\mathrm{LG}=$ Linkage group ALS $=$ Angular leaf Spot PWM= Powdery Mildew

A

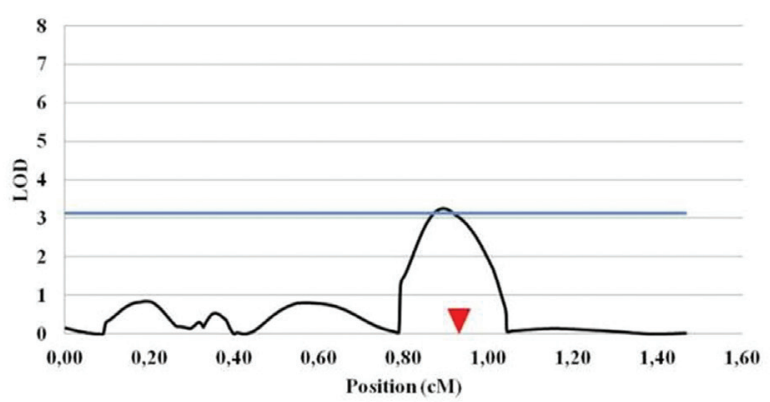

C

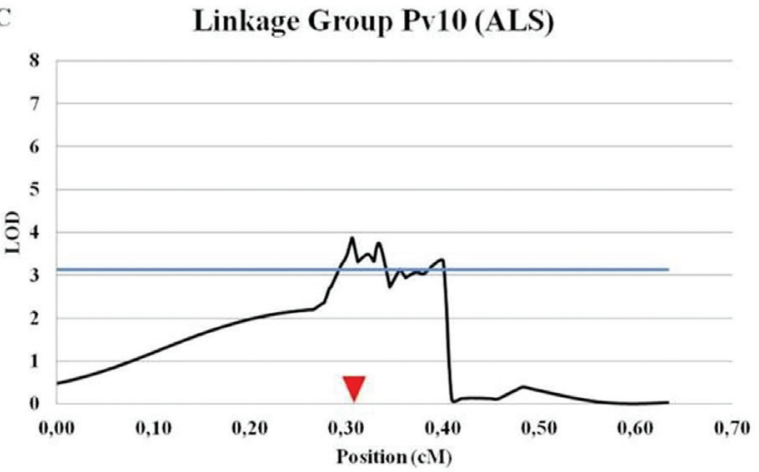

E

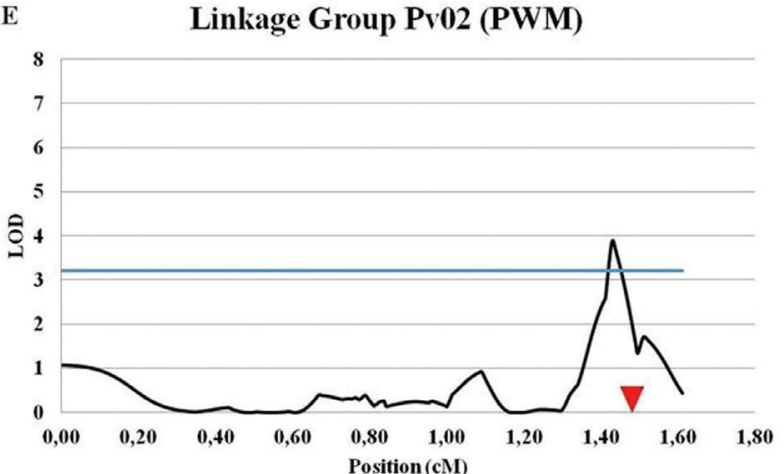

Linkage Group Pv06 (ALS)

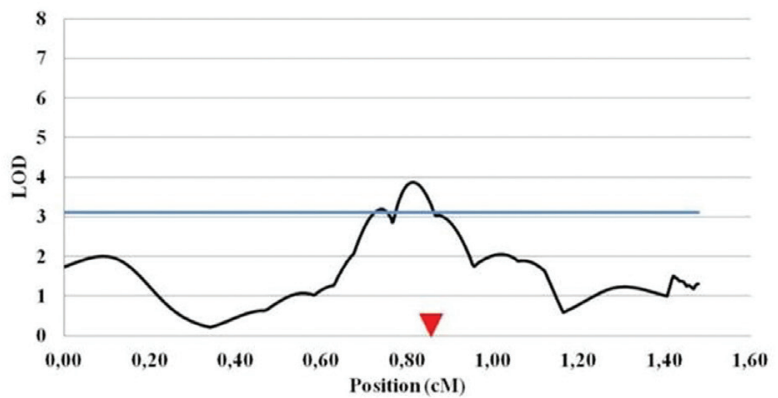

D

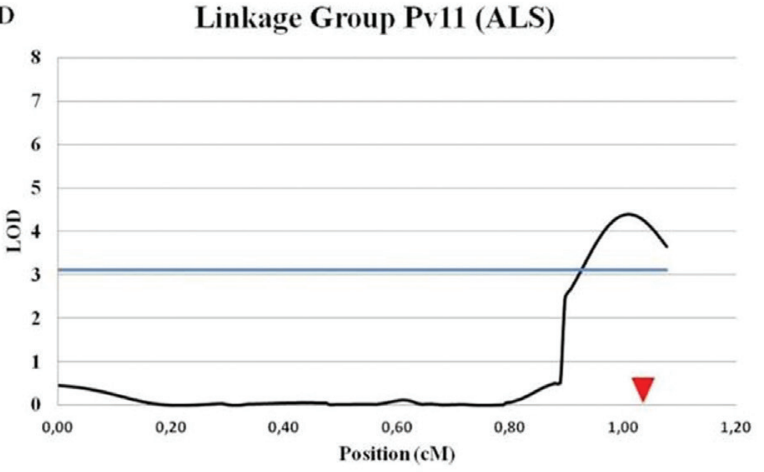

F
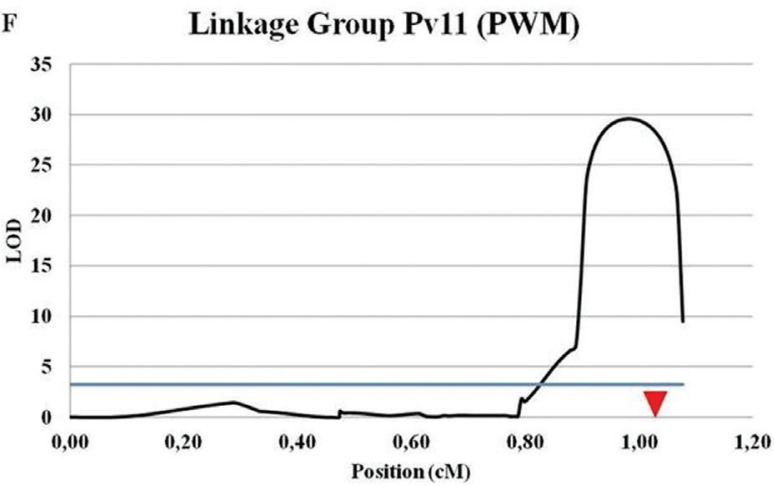

QTL

Figure 2 - QTL likelihood plots found by CIM analysis for the identification of resistance QTLs mapped in the genetic map developed from the AND 277 $x$ SEA 5(AS) population. QTLs associated to angular leaf spot (ALS) were referred as A to D and QTLs associated to powdery mildew (PWM) were referred as $\mathrm{E}$ and $\mathrm{F}$. 
leaf spot resistance on Pv10 (ALS10.1). The putative R genes cluster at ALS10.1 was shown to be down-regulated in the infected susceptible parent (IAC-UNA) suggesting its contribution to plant susceptibility to the fungus (Oblessuc et al., 2015).

In our study, a major effect QTL associated to ALS resistance was the ALS11 ${ }^{\mathrm{AS}}$, located on Pv11, which explained $26 \%$ of the phenotypic variance (Table 3), while the $\mathrm{ALS5}^{\mathrm{AS}}$, mapped on Pv5, explained $15 \%$ of the phenotypic variation.

For PWM, the PWM11AS resistance QTL had a major effect on the resistance, explaining $66 \%$ of the phenotypic variation (Table 3). This locus also presented the highest LOD value (29.6), which strongly supports superior accuracy. Ferreira et al. (1999) reported that reactions of common bean genotypes against powdery mildew under controlled conditions provided clear evidence about the qualitative nature of resistance involving different modes of inheritance. This qualitative nature was supported in this study by the detection of a major effect QTL (PWM11AS). For PWM, other resistance genes were mapped at the end of Pv04 and Pv11 (Trabanco et al., 2012; Pérez-Vega et al., 2013), using 'Cornell 49242' as source of resistance. The $\mathrm{Co}-2$ region (end of the Pv11) has been described previously (David et al., 2009). In our study, the PWM2AS, mapped on Pv02, explained 7\% of the phenotypic variation. Resistance genes and/or QTLs for many bean pathogens were found on Pv02, confirming the existence of $\mathrm{R}$ gene cluster on this chromosome (Hanai et al., 2007; Oblessuc et al., 2014; Campa et al., 2014). Keller et al. (2015) reported a major QTL (ALS4.1 $1^{\mathrm{GS}, \mathrm{UC}}$ ), localized on chromosome Pv04, that explained $75.3 \%$ of the ALS resistance.

The QTLs ALS11 ${ }^{\mathrm{AS}}$ and PWM11 ${ }^{\mathrm{AS}}$ presented the greatest effect on both diseases. These alleles derived from AND 277 are located within the same region on the Pv11, having the same marker linked (BAR5054) and close interval values (78.6-107.7 cM; 79.3-107.7 cM). However, for the ALS resistance, these alleles contributed for the reduction of the severity of the disease, while for PWM, they were associated with susceptibility. Thus, the AND 277 alleles conferred resistance to ALS, but contributed to the susceptibility to PWM. The presence of four resistance QTLs related to the response to ALS, resulting in a variable magnitude of phenotypic effects, indicated a complex pattern of inheritance for resistance to this disease in the AND 277 cultivar. Previous studies (Corrêa et al., 2001; Faleiro et al., 2004; Caixeta et al., 2005) reported contrasting results supporting a monogenic pattern of inheritance for resistance to ALS. However, most of these reports evaluated the resistance in a qualitative fashion, forcing the classification of the genotypes into two distinct phenotypic classes (resistant or susceptible), a binomial distribution, instead of using the whole set of notes from the 0-9 scale.
Other QTL studies supported a quantitative nature of ALS resistance (Lopez et al., 2003; Teixeira et al., 2005; Mahuku et al., 2011; Oblessuc et al., 2012; Keller et al., 2015). Mahuku et al. (2011), using a range of quantitative evaluations, found three genes for angular leaf spot resistance on the G5686 line and two on the G10909 line.

Our report provides the identification of new resistance loci for ALS and PWM resistance in common beans, revealing a quantitative pattern of inheritance to both diseases. The QTLs discovered in this study help to move bean resistance breeding toward a more efficient marker-assisted selection approach. The success of implementing a marker-assisted selection program depends on several factors such as a genetic map with molecular markers linked to genes controlling qualitative or quantitative traits of agronomic interest and a close association between markers and genes or QTL. Although the estimates presented here are for a particular breeding population, the common bean genome available on the Phytozome allows validating effective ALS and PWM resistance regions giving robustness to the estimates.

\section{Identification of putative resistance genes}

BLAST searches (Tables 4 and 5) on the Phytozome revealed genes related to the immune response in plants such as glycosyl hydrolase, iron transporter, and receptor-like kinases (RLK).

Limiting invasion by PWM in $A$. thaliana seem not to involve signaling molecules such as ethylene, jasmonic acid or salicylic acid, but requires a syntaxin, glycosyl hydrolase and $\mathrm{ABC}$ transporter (Consonni et al., 2006). Here, the Phvul.002G167200 gene, coding a putative glycosyl hydrolase, was identified in the PWM2 QTL and contains the sequence of the PVBR149 marker (Figure 1 and Table 3). Its homolog in Arabidopsis thaliana (AT4G36360) was shown to respond to germinivirus (Ascencio-Ibáñez et al., 2008), indicating the importance of this gene/QTL to PWM resistance.

Cross talk between metal and biotic stress signaling is still not fully solved, but it is known that adequate intracellular concentrations of essential metal ions are required for pathogen virulence and plant defenses (Poschenrieder $e t$ al., 2006).

RLKs are important pattern recognition receptors (PRRs) that play an important role in self- and non-selfrecognition, including the perception of hormones (Shiu and Bleecker, 2001), PAMPs, and pathogen effectors. Several RLKs involved in plant immunity have been identified, such as Xa21 (Song et al., 1998), Pto (Sessa et al., 2000), Flagellin Sensing 2 (FLS2) (Chinchilla et al., 2006) and BRASSINOSTEROID INSENSITIVE 1-ASSOCIATED KINASE 1 (BAK1) (Chinchilla et al., 2007), among many others. This family of proteins has also been associated to ALS resistance (Keller et al., 2015) in beans and for PWM resistance in wheat (Cao et al., 2011). The RLKs identified 


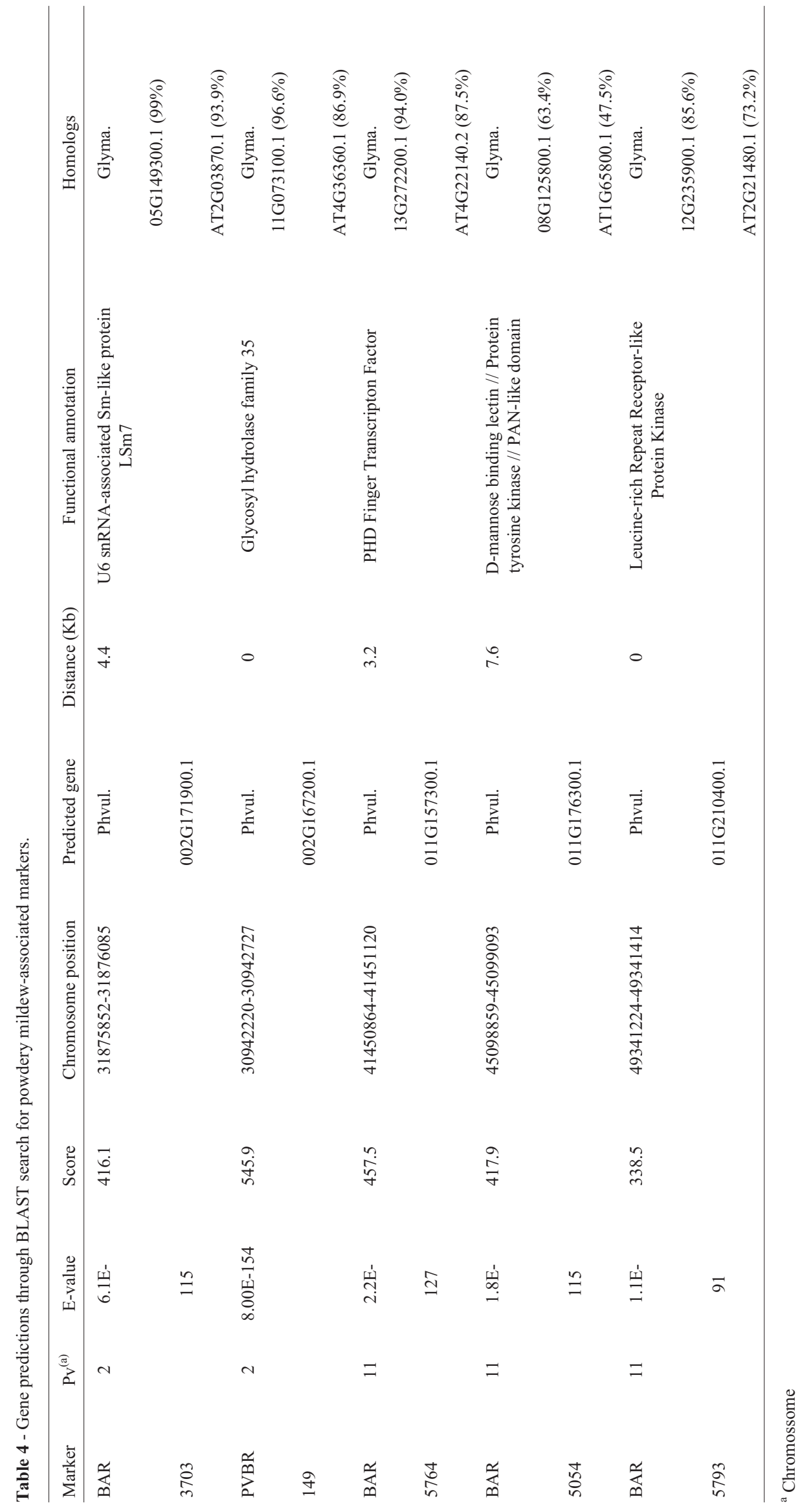




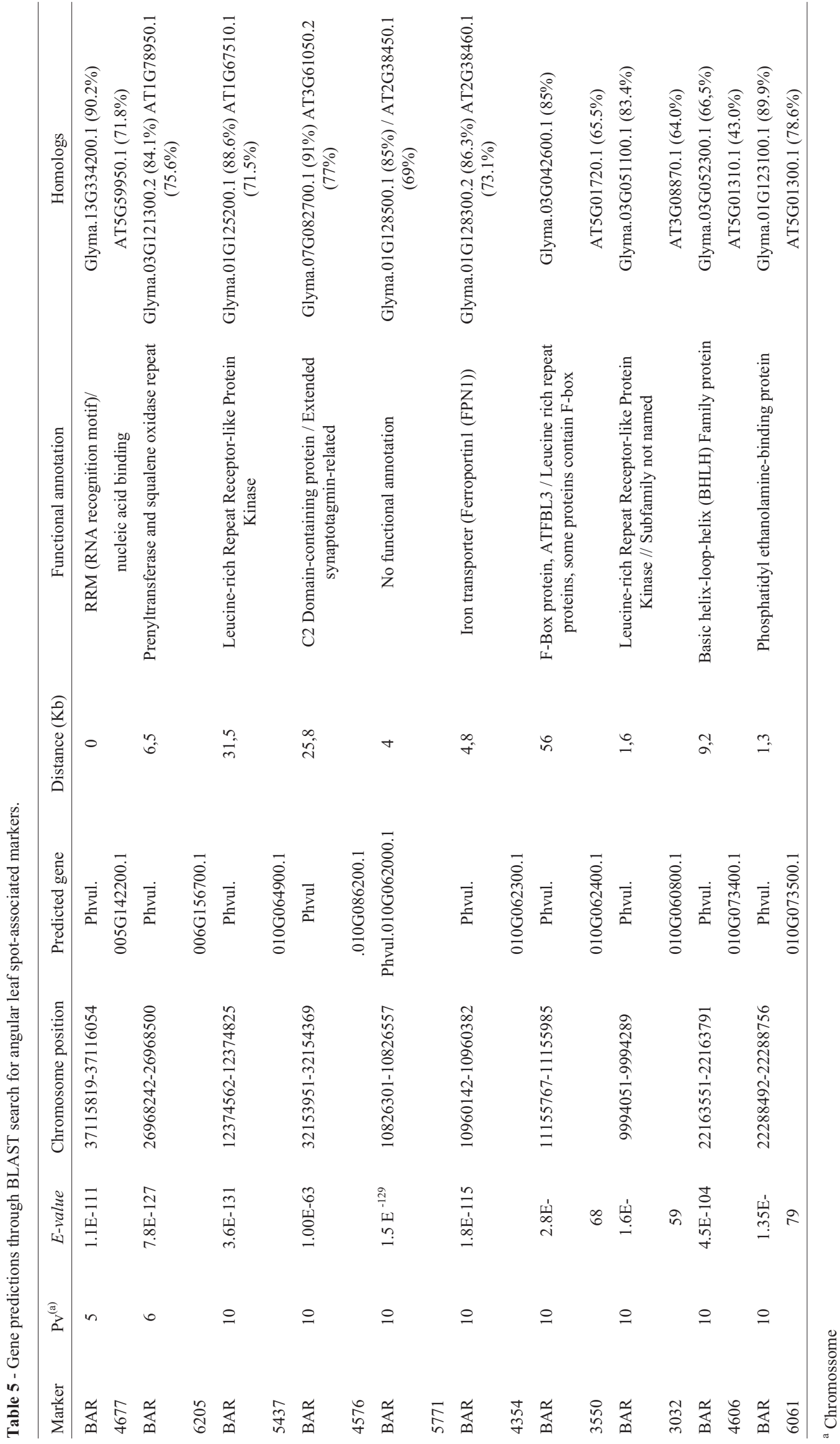


in our study such as Phvul.010G064900 and Phvul.010G060800, associated to the ALS10 QTL, besides Phvul.011G176300 and Phvul.011G210400, positioned at the ALS11 and PWM11 QTLs constitute promising candidate genes for triggering the resistance response to ALS and PWM.

\section{Acknowledgments}

This work was financially supported by FAPESP (grants 2010/51186-9 and 2010/51673-7).

\section{References}

Aggarwal VD, Pastor-Corrales MA, Chirw RMA and Buruchara RA (2004) Andean beans (Phaseolus vulgaris L) with resistance to the angular leaf pathogen (Phaeoisariopsisgriseola) in Southern and Eastern Africa. Euphytica 136:201-210.

Altschul SF, Madden TL, Schaffer A, Zhang J, Zhang Z, Miller W and Lipman DJ (1997) Gapped BLAST and PSI-BLAST: A new generation of protein database search programs. Nucleic Acids Res 25:3389-3402.

Alzate-Marin AL, Costa MR, Arruda KM, Barros EG and Moreira MA (2003) Characterization of the anthracnose resistance gene present in Ouro Negro (Honduras 35) common bean cultivar. Euphytica 13:165-169.

Amaro GB, Abreu AFB, Ramalho MAP and Silva FB (2007) Phenotypic recurrent selection in the common bean (Phaseolus vulgaris L) with carioca-type grains for resistance to the fungi Phaeoisariopsis griseola and identification of RAPD markers linked to the resistance gene. Euphytica 134:297-303.

Arruda KMA, Alzate-Marin AL, Oliveira MSG, Barros EG and Moreira MA (2008) Inheritance studies for anthracnose resistance genes of common bean cultivar AND 277. Bean Improvement Cooperative 51:170-171.

Ascencio-Ibañez TJ, Sozzani R, Lee T-J, Chu T-M, Wolfinger RD, Cella R and Hanley-Bowdoin L (2008) Global analysis of Arabidopsis gene expression uncovers a complex array of changes impacting pathogen response and cell cycle during geminivirus infection. Plant Physiol 148:436-454.

Basten CJ, Weir BS and Zeng ZB (2005) QTL Cartographer Version 1.17: A Reference Manual and Tutorial for QTL Mapping. North Carolina State University, Raleigh, 189 p.

Beebe S, Rao IM, Cajiao I and Grajales M (2008) Selection for drought resistance in common bean also improves yield in phosphorus limited and favorable environments. Crop Sci 48:582-592.

Blair MW, Giraldo MC, Buendía HF, Tovar E, Duque MC and Beebe SE (2006) Microsatellite marker diversity in common bean (Phaseolus vulgaris L.). Theor Appl Genet 113:100109.

Blair MW, Rodriguez PLM, Pedraza F, Morales F and Beebe S (2007) Genetic mapping of the bean golden yellow mosaic geminivirus resistance gene bgm1 and linkage with potyvirus resistance in common bean (Phaseolus vulgaris L.). Theor Appl Genet 114:261-271.

Blair MW, Torres MM, Giraldo MC and Pedraza F (2009) Development and diversity of Andean-derived, gene-based microsatellites for common bean (Phaseolus vulgaris L.). BMC Plant Biol 9:e100.
Blair MW, Hurtado N, Chavarro CM, Muñoz-Torres MC, Giraldo MC, Pedraza F, Tomkins J and Wing R (2011) Gene-based SSR markers for common bean (Phaseolus vulgaris L.) derived from root and leaf tissue ESTs: An integration of the BMc series. BMC Plant Biol 11:e50.

Blum LEB, Amarante CVT, Arioli CJ, Guimarães LS, Dezanet A, Neto PH and Scheidt FR (2003) Reaction of Phaseolus vulgaris genotypes to stem rot and powdery mildew. Fitopatol Bras 28:96-100.

Briñez Rodriguez, B (2013) Desenvolvimento da Plataforma DART e Mapeamento de Locos Associados com Tolerância à Seca em Feijão (Phaseolus vulgaris L.). Tese de Doutorado, Universidade Estadual de Campinas, 132 p.

Caixeta ET, Borém A, Alzate-Marin AL, Fagundes SD, Silva M, Barros EG and Moreira MA (2005) Allelic relationships for genes that confer resistance to angular leaf spot in common bean. Euphytica 145:237-245.

Campa A, Rodríguez-Suárez C, Giraldez R and Ferreira, JJ (2014) Genetic analysis of the response to eleven Colletotrichum lindemuthianum races in a RIL population of common bean (Phaseolus vulgaris L.). BMC Plant Biol 14:e115.

Campos T, Oblessuc PR, Sforça DA, Cardoso JMK, Baroni RM, Sousa ACB, Carbonell SAM, Chioratto AF, Rubiano LLB and Souza AP (2011) Inheritance of growth habit detected by genetic linkage analysis using microsatellites in the common bean (Phaseolus vulgaris L.). Mol Breed 27:549-560.

Cao A, Xing L, Wang X, Yang X, Wang W, Sun Y, Qian C, Ni J, Chen Y, Liu D, et al. (2011) Serine/threonine kinase gene Stpk-V, a key member of powdery mildew resistance gene Pm21, confers powdery mildew resistance in wheat. Proc Natl Acad Sci USA 108:7727-7732.

Carvalho GA, Paula TJ, Alzate-Marin AL, Nietsche S, Barros EG and Moreira MA (1998) Inheritance of resistance to angular leaf spot of common bean in AND 277 to race 63.23 of Phaeiosariopsis griseola and identification of RAPD marker linked to the resistance gene. Phytopathol Braz 23:482485.

CIMMYT (2005) Laboratory Protocols: CIMMYT Applied Molecular Genetics Laboratory. $3^{\text {rd }}$ ed. CIMMYT, Mexico City, $102 \mathrm{p}$.

Chinchilla D, Bauer Z, Regenass M, Boller T and Felix G (2006) The Arabidopsis receptor kinase FLS2 binds flg22 and determines the specificity of flagellin perception. Plant Cell 18:465-476.

Chinchilla D, Zipfel C, Robatzek S, Kemmerling B, Nürnberger T, Jones JDG, Felix G and Boller T (2007). A flagellininduced complex of the receptor FLS2 and BAK1 initiates plant defense. Nature 448:497-500.

Churchill GA and Doerge RW (1994) Empirical threshold values for quantitative trait mapping. Genetics 138:963-971.

Consonni C, Humphry ME, Hartmann HA, Livaja M, Durner J, Westphal L, Vogel J, Lipka V, Kemmerling B, SchulzeLefert P, et al. (2006) Conserved requirement for a plant host cell protein in powdery mildew pathogenesis. Nat Genet 38:716-720.

Córdoba JM, Chavarro C, Rojas F, Muñoz C and Blair MW (2010) Identification and mapping of simple sequence repeat markers from common bean (Phaseolus vulgaris L.) bacterial artificial chromosome end sequences for genome characterization and genetic-physical map integration. Plant Genome 3:154-165. 
Corrêa RX, Pedro IV, Oliveira MLP, Nietsche S, Moreira M and Barro EG (2001) Inheritance of resistance to the common bean angular leaf spot and identification of molecular markers flanking the resistance locus. Phytopathol Braz 26:2732.

Crous PW, Liebenberg MM, Braun U and Groenewald JZ (2006) Re-evaluating the taxonomic status of Phaeoisariopsis griseola, the causal agent of angular leaf spot of bean. Stud Mycol 55:163-173.

David P, Chen NWG, Pedrosa-Harand A, Thareau V, Sévignac M, Cannon SB, Debouck D, Langin T and Geffroy V (2009) A nomadic subtelomeric disease resistance gene cluster in common bean. Plant Physiol 151:1048-1065.

Ender M and Kelly JD (2005) Identification of QTL associated with white mold resistance in common bean. Crop Sci 45:2482-2490.

Faleiro FG, Ragagnin VA, Moreira MA and Barros EG (2004) Use of molecular markers to accelerate the breeding of common bean lines resistant to rust and anthracnose. Euphytica 138:213-218.

Falconer DS and Mackay TFC (1996) An Introduction to Quantitative Genetics. $4^{\text {th }}$ ed. Prentice Hall, London, 480 p.

Ferreira RV, Ramalho MAP and Corte HR (1999) Genetic control of common bean (Phaseolus vulgaris L.) resistance to powdery mildew (Erysiphe polygoni). Genet Mol Biol 22:233236.

Gaitán-Solís E, Choi IY, Quigley C, Cregan P and Tohme J (2008) Single nucleotide polymorphisms in common bean: Their discovery and genotyping using a multiplex detection system. Plant Genome 1:125-134.

Garcia RAV, Rangel PN, Brondani C, Martins WS, Melo LC, Carneiro MS, Borba TCO and Brondani RPV (2011) The characterization of a new set of EST-derived simple sequence repeat (SSR) markers as a resource for the genetic analysis of Phaseolus vulgaris. BMC Genet 12:e41.

Gepts P, Moore PH, Aragão FJL, Barros E, Blair MW, Brondani R, Broughton W, Galasso I, Hernández G, Kami J, et al. (2008) Genomics of tropical crop plants. Genomics of Phaseolus beans, a major source of dietary protein and micronutrients in the tropics. In: Moore PH and Ming $\mathrm{R}$ (eds) Plant Genetics and Genomics: Crops and Models. Springer, New York, pp 113-143.

Gonçalves-Vidigal MC, Cruz AS, Garcia A, Kami J, VidigalFilho OS, Sousa LL, McClean P, Gepts P and Pastor-Corrales MA (2011) Linkage mapping of the Phg-1 and Co- ${ }^{4}$ genes for resistance to angular leaf spot and anthracnose in the common bean cultivar AND 277. Theor Appl Genet 122:893-903.

Grisi MCM, Blair MW, Gepts P, Brondani C, Pereira PAA and Brondani RPV (2007) Genetic mapping of a new set of microsatellite markers in a reference common bean (Phaseolus vulgaris) population BAT93 x Jalo EEP558. Genet Mol Rese 6:691-706.

Hall R (1991) Compendium of Bean Diseases. American Phytopathological Society Press, St. Paul, 73 pp.

Hanai LR, Campos T, Camargo LEA, Benchimol LL, Souza AP, Melotto M, Carbonell SAM, Chioratto AF, Consoli L, Formighieri EF, et al. (2007) Development characterization and comparative analysis of polymorphism at common bean SSR loci isolated from genic and genomic sources. Genome 50:266-277.
Hanai LR, Santini L, Camargo LEA, Fungaro MHP, Gepts P, Tsai SM and Vieira MLC (2010) Extension of the core map of common bean with EST-SSR, RGA, AFLP, and putative functional markers. Mol Breed 25:25-45.

Jesus Júnior WC, Vale FXR, Coelho RR, Hau B, Zambolin L, Costa LC and Bergamin Filho A (2001) Effects of angular spot and rust on yield loss of Phaseolus vulgaris. Phytopathology 92:1045-1053.

Jung G (1998) Mapping genes for specific and adult plant resistance to rust and abaxial leaf pubescence and their genetic relationships using randomly amplified polymorphic DNA (RAPD) markers in common bean. J Am Soc Horticul Sc 123:859-863.

Kasettranan W, Somta P and Srinives P (2010) Mapping of quantitative trait loci controlling powdery mildew resistance in mung bean (Vigna radiata (L.) Wilczek). J Crop Sc Biotechnol 13:155-161.

Keller B, Manzanares C, Jara C, Lobaton JD, Studer B and Raatzn B (2015) Fine-mapping of a major QTL controlling angular leaf spot resistance in common bean (Phaseolus vulgaris L.). Theor Appl Genet 128:813-826.

Kolkman JM and Kelly JD (2003) QTL conferring resistance and avoidance to white mold in common bean. Crop Sci 43:539-548.

Kosambi DD (1944) The estimation of map distances from recombinant values. Ann Eugenics 12:172-175.

López CE, Acosta IF, Jara C, Pedraza F, Gaitán-Solís E, Gallego $\mathrm{G}$, Beebe $\mathrm{S}$ and Tohme J (2003) Identifying resistance gene analogs associated with resistances to different pathogens in common bean. Phytopathology 93:88-95.

Lynch M and Walsh B (1998) Genetics and Analysis of Quantitative Traits. Sinauer Associates, Sunderland, 980 p.

Mahuku GS, Jara C, Cajiao C and Beebe S (2003) Sources of resistance to angular leaf spot (Phaeoisariopsis griseola) in common bean core collection, wild Phaseolus vulgaris and secondary gene pool. Euphytica 130:303-313.

Mahuku GS, Iglesias AM and Jara C (2009) Genetics of angular leafspot resistance in the Andean common bean accession G5686and identification of markers linked to the resistance genes. Euphytica 167:381-396.

Mahuku GS, Henryquez MA, Montoya C, Jara C, Teran H and Beebe $S$ (2011) Inheritance and development of molecular markers linked to angular leaf spot resistance genes in the common bean accession G10909. Mol Breed 28:57-71.

Mardia KV (1970) Measures of multivariate skewness and kurtosis with applications. Biometrika 57:519-530.

Margarido GRA, Souza AP and Garcia AAF (2007) OneMap: Software for genetic mapping in outcrossing species. Hereditas 144:78-79.

Melo LC, Santos JB and Ferreira DF (2002) QTLs mapping for reaction to powdery mildew and angular leaf spot of common bean in different locations. Pesq Agropec Bras 37:11151126.

Miklas PN (2007) Marker-assisted backcrossing QTL for partial resistance to Sclerotinia white mold in dry bean. Crop Sci 47:935-942.

Miklas PN, Johnson WC, Delorme R and Gepts P (2001) QTL conditioning physiological resistance and avoidance to white mold in dry bean. Crop Sci 41:309-315.

Müller BSF, Pappas GJ, Valdisser PAMR, Coelho GRC, Menezes IPP, Abreu AG, Borba TCO, Sakamoto T, Brondani C, 
Barros EG, et al. (2015) An operational SNP panel integrated to SSR marker for the assessment of genetic diversity and population structure of the common bean. Plant Mol Biol Rep 33:1697-1711.

Navarro F, Skroch P, Jung G and Nienhuis J (2007) Quantitative trait loci associated with bacterial brown spot in Phaseolusvulgaris L. Crop Sci 47:1344-1353.

Oblessuc PR, Baroni RM, Garcia AAF, Chioratto AF, Carbonell SAM, Camargo LEA and Benchimol LL (2012) Mapping of angular leaf spot resistance QTL in common bean (Phaseolus vulgaris L.) under different environments. BMC Genet 13:e50.

Oblessuc PR, Perseguini JMKC, Baroni RM, Chiorato AF, Carbonel SAM, Mondengo JMC, Vidal RO, Camargo LEA and Benchimol-Reis LL (2013) Increasing the density of markers around a major QTL controlling resistance to angular leaf spot in common bean. Theor Appl Genet 26:2451-2465.

Oblessuc PR, Baroni RM, da Silva Pereira G, Chiorato AF, Carbonell SAM, Briñez B, Da Costa e Silva L, Garcia AAF, Camargo LEA, Kelly JD, et al. (2014) Quantitative analysis of race-specific resistance to Colletotrichum lindemuthianum in common bean. Mol Breed 34:13131329.

Oblessuc PR, Matioli CC, Chiorato AF, Benchimol-Reis LL and Melotto M (2015) Common bean reaction to angular leaf spot comprises transcriptional modulation of genes in the ALS10.1 QTL. Front Plant Sci 6:e152.

Pastor-Corrales MA and Jará CE (1995) The evolution of Phaseolus vulgaris with the common bean in Latin America. Fitopatol Colomb 19:15-24.

Pastor-Corrales MA, Jara CE and Singh SP (1998) Pathogenic variation in, sources of, and breeding for resistance to Phaeoisariopsis griseola causing angular leaf spot in common bean. Euphytica 103:161-171.

Pedrosa-Harand A, Porch T and Gepts P (2008) Standard nomenclature for common bean chromosomes and linkage groups. Bean Improv Coop 51:106-107.

Pérez-Vega E, Trabanco N, Campa A and Ferreira JJ (2013) Genetic mapping of two genes conferring resistance to powdery mildew in common bean (Phaseolus vulgaris L.). Theor Appl Genet 126:1503-1512.

Poschenrieder C, Tolra R and Barcelo J (2006) Can metals defend plants against biotic stress? Trends Plant Sci 11:288-295.

R Development Core Team (2011) R: A language and environment for statistical computing. R Foundation for Statistical Computing, Vienna.

Rasband WS (2014) ImageJ, US National Institutes of Health, Bethesda, Maryland, USA, http://imagej.nih.gov/ij/.

Rao IM, Polania J, Garcia R and Beebe S (2006) Development of a greenhouse soil tube method to quantify phenotypic differences among advanced lines in root development and distribution under drought stress. In: Centro Internacional de Agricultura Tropical (ed), Annual Report. Project IP-1: Bean Improvement for the Tropics (2006). CIAT, Cali, pp 19-25.

Reis-Prado FG (2006) Reaction of common bean cultivars to angular leaf spot in the green house. Fitopatol Bras 31:306309.

Rezende VF, Ramalho MAP and Corte HR (1999) Genetic control of common bean (Phaseolus vulgaris) resistant to pow- dery mildew (Erysiphe polygoni). Genet Mol Biol 22:233236.

Sartorato A (2002) Identification of Phaeoisariopsis griseola pathotypes in five States in Brazil. Fitopatol Bras 27:78-81.

Sartorato A (2006) New sources of resistance to angular leaf spot on common bean. Fitopatol Bras 31:192-194.

Sartorato A, Rava AC and Rios GP (1996) Fungical and bacterial foliar diseases. In: Araujo R, Rava CA, Stone LF and Zimmermann MJ de O (eds) Common Bean Crop in Brazil. Potafos, Piracicaba, 296 p.

Schmutz J, McClean PE, Mamidi S, Wu GA, Cannon SB, Grimwood J, Jenkins J, Shu S, Song Q, Chavarro C, et al. (2014) A reference genome for common bean and genome-wide analysis of dual domestications. Nat Genet 46:707-13.

Schwartz HF (1994) Additional pathogenic fungi. In: Pastor-Corrales MA and Schwartz HF (eds) Bean Production Problems in the Tropics. CIAT, Cali, pp 268-301.

Schwartz HF, Katherman MJ and Thung MDT (1981) Yield response and resistance of dry beans to powdery mildew in Colombia. Plant Dis 65:737-738.

Schwartz HF, Pastor-Corales MA and Singh SP (1982) New source of resistance to anthracnose and angular leaf spot of beans (Phaseolus vulgaris L.). Euphytica 31:741-754.

Schwartz HF, Steadman JR, Hall R and Forster RL (2005) Compendium of Bean Diseases. 2nd ed. APS Press, St. Paul, pp 109-131.

Sessa G, D'Ascenzo M and Martin GB (2000) Thr38 and Ser198 are Pto auto phosphorylation sites required for the Avr Pto-Pto-mediated hypersensitive response. EMBO J 19:2257-2269.

Shapiro SS and Wilk MB (1965) An analysis of variance test for normality (complete samples). Biometrika 52:591-611.

Shiu SH and Bleecker AB (2001) Receptor-like kinases from Arabidopsis form a monophyletic gene family related to animal receptor kinases. Proc Natl Acad Sci U S A 98:1076310768 .

Silva KJD, De Souza EA, Sartorato A and Freire CND (2008) Pathogenic variability of isolates of Pseudocercospora griseola, the cause of common bean angular leaf spot, and its implications for resistance breeding. J Phytopathol 156:602-606

Singh SP, Terán H and Gutierrez JA (2001) Registration of SEA 5 and SEA 13 drought tolerant dry bean germplasm. Crop Sci 41:276-277.

Song W-Y, Pi L-Y, Bureau TE and Ronald PC (1998) Identification and characterization of 14 transposon-like elements in the noncoding regions of members of the $\mathrm{Xa21}$ family of disease resistance genes in rice. Mol Gen Genet 258:449-456.

Souza TLPO, Barros EG, Bellato CM, Hwang EY, Cregan PB and Pastor-Corrales MA (2012) Single nucleotide polymorphism discovery in common bean. Mol Breed 30:419-428.

Teixeira FF, Santos JB dos, Ramalho MAP, Abreu A de FB, Guimarães CT and Oliveira AC de (2005) QTL mapping for angular leaf spot in common bean using microsatellite markers. Crop Breeding and Applied Biotechnology 5:272-278.

Terán H and Singh SP (2002) Comparison of sources and lines selected for drought resistance in common bean. Crop Sci 42:64-70.

Trabanco T, Pérez-Vega E, Campa A, Rubiales D and Ferreira JJ (2012) Genetic resistance to powdery mildew in common bean. Euphytica 186:875-882. 
Van-Schoonhoven A and Pastor-Corrales MA (1991) Sistema estándar para La evaluación de germoplasma de Frijol. CIAT, Cali, pp 20-46.

Voorrips RE (2002) MapChart: Software for the graphical presentation of linkage maps and QTLs. J Hered 93:77-78.

Yu K, Park SJ, Poysa V and Gepts P (2000) Integration of simple sequence repeat (SSR) markers into a molecular linkage map of common bean (Phaseolus vulgaris L.). J Hered 91:429-434.

Zeng ZB, Kao CH and Basten CJ (1999) Estimating the genetic architecture of quantitative traits. Gene Res 74:279-289.

\section{Internet Resources}

FAOStat (2014) FAO statistic. Food and agriculture organization of the united nations (FAO), Statistical database, Food and Agriculture. http://faostat.fao.org/ (accessed May 20, 2014).
Phytozome.net (2014) Phaseolus vulgaris v1.0. DOE-JGI and USDA-NIFA, https://phytozome.jgi.doe.gov/pz/portal.html (accessed May 10, 2014).

\section{Supplementary material}

This online material is available for this article:

Table S1 - Diagrammatic scale notes used to evaluate the reaction of RILs to powdery mildew.

Figure S1 - Processing and analyzing of digital images of parent leaves.

Figure S2 - Distribution of powdery mildew (PWM) and angular leaf spot (ALS).

Associate Editor: Marcia Pinheiro Margis

License information: This is an open-access article distributed under the terms of the Creative Commons Attribution License (type CC-BY), which permits unrestricted use, distribution and reproduction in any medium, provided the original article is properly cited. 